\title{
Experimental Analysis of Hybrid Energy Operated Refrigerator Coupled In EV
}

\author{
Surender Kumar, Rabinder Singh Bharj
}

\begin{abstract}
This paper is focused on the performance of a solar-assisted DC refrigerator installed on the backside of the electric vehicle $(E V)$. The experiments are performed by varying load conditions inside the refrigerator. The experimental setup consists of four solar PV panels, a charge controller, battery bank, voltage converter, $D C$ refrigerator, and an electric vehicle. The temperature inside the refrigerator cabin was controlled with the thermostat position adjustment. The solar $P V$ panels of the vehicle was generating 2.5-4 kWh energy on the average sunny day. The refrigerator's inside temperature was decreased with a faster rate at the third thermostat position and consuming higher energy at the seventh thermostat position among all load conditions. The fourth and fifth thermostat positions were better at maintaining the lower desired temperature inside the refrigerator cabin by consuming the minimum energy. The COP of the refrigerator was decreasing with the increasing compressor speed. The battery bank was able to run the refrigerator $240 \mathrm{hr}, 96 \mathrm{hr}, 72 \mathrm{hr}$ for the no-load, $15 \mathrm{~L}$ load, and $25 \mathrm{~L}$ load conditions at the higher thermostat position. The vehicle was travelling $68.3 \mathrm{~km}, 65.3 .6$ $\mathrm{km}, 63.4 \mathrm{~km}$ distance in no-load, $100 \mathrm{~kg}$, and $200 \mathrm{~kg}$ load conditions respectively by consuming $3010 \mathrm{Wh}, 3230 \mathrm{Wh}$, and 3450 Wh energy. The travelling charge of this vehicle was 1-1.5 INR per kilometer.
\end{abstract}

Keywords: Hybrid Energy Refrigerator, DC Compressor, Temperature Variation, Photovoltaic (PV), EV performance.

\section{INTRODUCTION}

\section{A. The Current Scenario in Perishable Foodstuff Transportation}

More than $40 \%$ of food delivery items require refrigeration, but only $15 \%$ of products use this facility due to energy shortfall worldwide. The refrigerated transport system is the core of the cold chain. The supply of perishable food items at a distant location depends on the refrigerated food transportation system [1]. Refrigerated vehicles such as trucks and vans play an essential role in the localized delivery of perishable foodstuffs. Globally, about 4 million food transport vehicles are available in the current market. More than $65 \%$ of these vehicles are using for milk and its products transportation. Only 35\% of vehicles are using for perishable

Manuscript received on March 12, 2021.

Revised Manuscript received on March 23, 2021.

Manuscript published on April 30, 2021.

* Correspondence Author

Surender Kumar*, Research Scholar, Mechanical Engineering Department, National Institute of Technology, Jalandhar (Punjab), India.

Dr. R.S. Bharj, Associate Professor, Mechanical Engineering Department, National Institute of Technology, Jalandhar (Punjab), India.

(c) The Authors. Published by Blue Eyes Intelligence Engineering and Sciences Publication (BEIESP). This is an open access article under the CC BY-NC-ND license (http://creativecommons.org/licenses/by-nc-nd/4.0/) foodstuff transportation [2]. The shelf life and quality of perishable foodstuffs highly depend on the storage temperature range of 5 to $-15{ }^{\circ} \mathrm{C}$. Today perishable foodstuff transportation is facing sustainability problems, especially in the urban area of developing countries.About 20\% more fuels are consuming by diesel engine vehicles integrated with the refrigeration system. These refrigerated vehicles are generating more GHG emissions [3-5]. Therefore, energy-efficient load-carrying vehicles are required in cold chain transportation (CCT) that produce the minimum amount of GHG emissions.

\section{B. Energy Consumption and Food Loss in the CCT}

Presently reliable and eco-friendly refrigeration system is needing in the CCT for temporary storage. Nearly 30\% of foodstuffs are wasting in the food supply chain (FSC) before the customer receives it. The perishable foods are wasting on the farm level due to environmental change, less availability of refrigerated vehicles, poor management, lack of cold chain infrastructures, and economic problems [6-7]. More than 15\% of total world energy is consumed in the refrigerated food supply chain (RFSC). This energy is generated by fossil fuels that again cause GHG emissions. The new fresh food demand is increasing worldwide in the FSC due to the increasing population and peoples' living standards in urban areas. Environmental conditions play a vital role in energy consumption and transportation cost in the FSC [8-12]. The quality decay of the food product starts if the perishable foodstuffs delivery time increases.

\section{Refrigerated Electric Vehicle Role in Smart City Foodstuff Delivery}

Currently, the transport sector releases 9000 billion tons of carbon dioxide $\left(\mathrm{CO}_{2}\right)$, which is expected to increase by $60 \%$ in 2050. The transportation sector oil demand continuously increases, which a serious issue. The cost of fossil fuels grows continuously in the past decades. The solar-assisted refrigerating electric vehicle (SAREV) is operationally eco-friendly and energy-efficient, which is a good alternative compared to conventional vehicles [13]. The impressive growth in the food supply chain has been recorded due to urbanization. About $50 \%$ of the world population lives in metro cities. The frozen food market is growing, with a $7 \%$ CAGR globally [14-16]. By the use of refrigeration during perishable foodstuff transportation, the bacteria growth controls inside foodstuff are possible. The alternative SAREV is smaller in size and can be suitable for timely foodstuff delivery in congested city zones.

In the current scenario, many developing countries need a reliable and energy-efficient approach to inter-city refrigerated

Blue Eyes Intelligence Engineering \& Sciences Publication

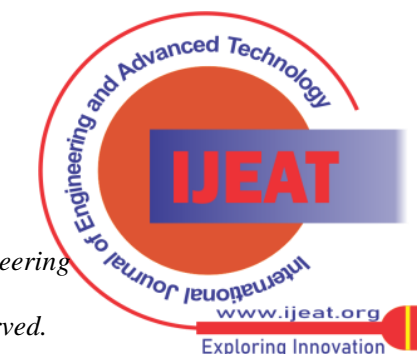




\section{Experimental Analysis of Hybrid Energy Operated Refrigerator Coupled In EV}

foodstuff transportation. This paper describes the experimentation on the refrigerator and electric vehicle that is used in the smart cold chain transportation.
Earlier reviews on the integral solar refrigerating system are briefed in Table 1.

Table- I: Review on Integral Solar Refrigerating System Performance

\begin{tabular}{|c|c|c|}
\hline Year \& reference & $\begin{array}{l}\text { Type of compressor \& working } \\
\text { refrigerant }\end{array}$ & Method \& experimental parameters \\
\hline \multirow[t]{2}{*}{$2009[16]$} & $\begin{array}{l}\text { AC compressor }(110 \mathrm{~W}) \text {; } \\
\text { R134a refrigerant. }\end{array}$ & $\begin{array}{l}\text { - Solar operated domestic refrigerator (SDR); } \\
\text { - The solar intensity with time, solar photovoltaic panel (SPV) current, and voltage; } \\
\text { - Freezer temperature and ambient temperature; } \\
\text { - COP of the refrigerator with time. }\end{array}$ \\
\hline & \multicolumn{2}{|c|}{ Short description: The COP of the refrigerator was decreased with sunrise; the maximum COP was recorded 2.1 at 7 am. } \\
\hline \multirow[t]{2}{*}{2013 [17] } & $\begin{array}{l}\text { 12V DC compressor; } \\
\text { R134a refrigerant. }\end{array}$ & $\begin{array}{l}\text { - Solar operated-variable speed direct current (VSDC) system; } \\
\text { - Speed of the compressor; } \\
\text { - Temperatures and pressures of refrigerating unit. }\end{array}$ \\
\hline & \multicolumn{2}{|c|}{ Short description: The COP of the VSDC-compressor was 0.38 at the speed of $2500 \mathrm{rpm}$; the exergy efficiency was $7.4 \%}$. \\
\hline \multirow[t]{2}{*}{2016 [18] } & $\begin{array}{l}\text { VSDC compressor; } \\
\text { R134a refrigerant. }\end{array}$ & $\begin{array}{l}\text { - AC and DC compressor operated with solar energy; } \\
\text { - Inside chamber temperatures; } \\
\text { - AC and DC refrigerator energy consumption; } \\
\text { - Speed of compressor; } \\
\text { - Solar energy generation in peak hours; } \\
\text { - Pull down-time. }\end{array}$ \\
\hline & \multicolumn{2}{|c|}{$\begin{array}{l}\text { Short description: The Solar operated DC refrigerator system installation cost was } 18 \% \text { less than the AC refrigerator; the AC refrigerator } \\
\text { consumed high power compared to the DC refrigerator. }\end{array}$} \\
\hline \multirow[t]{2}{*}{2016 [19] } & $\begin{array}{l}\text { DC compressor; } \\
\text { R134a refrigerant. }\end{array}$ & $\begin{array}{l}\text { - Milk cooling system with ice and DC refrigerator operated with solar energy; } \\
\text { - Ambient temperature and refrigerator chamber inside temperature; } \\
\text { - Battery current and voltage; } \\
\text { - Solar irradiance; } \\
\text { - PV current and voltage; } \\
\text { - Energy consumption of the refrigerator. }\end{array}$ \\
\hline & \multicolumn{2}{|c|}{ Short description: The refrigerating system was able to produce $12 \mathrm{~kg}$ of ice every day. } \\
\hline \multirow[t]{2}{*}{$2017[20]$} & $\begin{array}{l}\text { Solar absorption cooling system; } \\
\mathrm{NH}_{3}-\mathrm{H}_{2} \mathrm{O}(40: 60) \text {. }\end{array}$ & $\begin{array}{l}\text { - Solar absorption cooling system used for ice storage; } \\
\text { - Solar irradiance with time; } \\
\text { - PV current and voltage; } \\
\text { - Refrigerator chamber inside temperature; } \\
\text { - Heat output and flow rate for the cooling system. }\end{array}$ \\
\hline & \multicolumn{2}{|c|}{ Short description: The COP of the absorption chiller was recorded as $0.43,0.47$ in the March and October months, respectively. } \\
\hline \multirow[t]{2}{*}{2017 [21] } & $\begin{array}{l}\text { 12V DC-VCR compressor; } \\
\text { R134a refrigerant. }\end{array}$ & $\begin{array}{l}\text { - Battery and hybrid mode of load supply; } \\
\text { - The current and voltage of solar panel; } \\
\text { - Current, voltage consumed by refrigerator; } \\
\text { - Solar radiation and battery voltage; } \\
\text { - The inside temperature of the DC refrigerator chamber. }\end{array}$ \\
\hline & \multicolumn{2}{|c|}{ Short description: The refrigerator consumed 15-41\% more power in loaded condition than the no-load condition. } \\
\hline \multirow[t]{2}{*}{2018 [22] } & $\begin{array}{l}\text { AC compressor; } \\
\text { R134a refrigerant. }\end{array}$ & $\begin{array}{l}\text { - Solar operated ice thermal storage air-conditioning and refrigerating system; } \\
\text { - PV voltage and current; } \\
\text { - Voltage and current of the refrigerator; } \\
\text { - The inside temperature of the refrigerating unit; } \\
\text { - Battery bank voltage and current. }\end{array}$ \\
\hline & \multicolumn{2}{|c|}{$\begin{array}{l}\text { Short description: The thermal ice storage was feasible to use instead of the battery bank to store solar energy in the field of distributed } \\
\text { photovoltaic refrigeration. }\end{array}$} \\
\hline \multirow[t]{2}{*}{2018 [23] } & $\begin{array}{l}\text { 12V-24V DC-VCR compressor; } \\
\text { R134a refrigerant. }\end{array}$ & $\begin{array}{l}\text { - } 12 \mathrm{~V} \text { and 24V PV DC refrigerator by varying operating condition; } \\
\text { - Compressor run time, current, and power; } \\
\text { - The temperature inside the DC refrigerator; } \\
\text { - The energy produced by solar panels. }\end{array}$ \\
\hline & \multicolumn{2}{|c|}{ Short description: The DC-refrigerator work was more efficient at $12 \mathrm{~V}$ as compared to $24 \mathrm{~V}$. } \\
\hline \multirow[t]{2}{*}{2019 [24] } & $\begin{array}{l}\text { VSDC compressor; } \\
\text { R134a refrigerant. }\end{array}$ & $\begin{array}{l}\text { - Directly coupled vapor compression (DCVC) solar refrigeration system; } \\
\text { - Compressor speed range } 1800-4200 \mathrm{rpm} \text {; } \\
\text { - Current and voltage generated by the PV panel. }\end{array}$ \\
\hline & \multicolumn{2}{|c|}{$\begin{array}{l}\text { Short description: The COP of the refrigerator was higher (2.25) at lower compressor speed and recorded the lowest (1.85) at higher } \\
\text { compressor speed. }\end{array}$} \\
\hline \multirow[t]{2}{*}{2020 [25] } & $\begin{array}{l}\text { DC compressor; } \\
\text { HC-600a and HFC-134a refrigerant. }\end{array}$ & $\begin{array}{l}\text { - Milk cooling with ice and DC refrigerator operated with solar energy; } \\
\text { - Milk cooling time and temperature inside the freezer; } \\
\text { - Ambient temperature and energy consumption of the refrigerator. }\end{array}$ \\
\hline & \multicolumn{2}{|c|}{ Short description: The COP of the HC-600a circuit was 1.22; the COP of the HFC134a circuit was 1.24. } \\
\hline
\end{tabular}

Published By:

Blue Eyes Intelligence Engineering

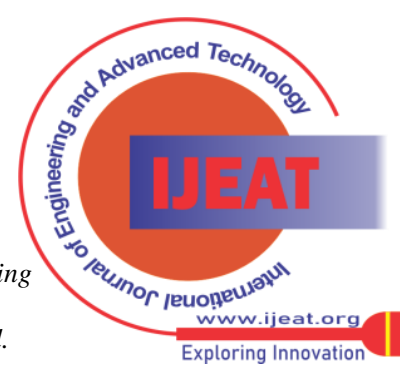




\begin{tabular}{|c|c|c|}
\hline \multirow[t]{2}{*}{$2021[26]$} & $\begin{array}{l}\text { 12V DC compressor; } \\
\text { R134a refrigerant. }\end{array}$ & $\begin{array}{l}\text { - Hybrid (bat } \\
\text { - Vehicle spe } \\
\text { - Current and }\end{array}$ \\
\hline & \multicolumn{2}{|c|}{$\begin{array}{l}\text { Short description: The refrigerator energy was lower in th } \\
\text { The vehicle weight was reduced by } 20 \mathrm{~kg} \text { which enhance }\end{array}$} \\
\hline \multicolumn{3}{|c|}{$\begin{array}{l}\text { The AC operated refrigerator is consumed } 25-40 \% \text { more } \\
\text { power as compared to the DC-refrigerator [17-30]. The } \\
\text { refrigerating system's performance depends on the } \\
\text { metrological conditions and thermostat position; but, no } \\
\text { information about the integral system of the SAREV has been } \\
\text { found in the past literature studies. Therefore, the present } \\
\text { research work focuses on the integral system performance } \\
\text { coupled in the electric vehicle. The integral system of SAREV } \\
\text { is built up, and field tests are carried in different conditions. }\end{array}$} \\
\hline
\end{tabular}

\section{DESCRIPTION OF EXPERIMENTAL SETUP}

The experimental set-up consists of a $12 \mathrm{~V} \mathrm{DC}$ refrigerator (240 L), solar energy production unit (48 V \& 600 W), Pulse width modulation (PWM) solar charge controller, and battery bank (48 V \& $105 \mathrm{Ah}$ ). The refrigerator is fitted on the backside of this vehicle purchased from Phocos India Solar Pvt Ltd. The solar charge controller and PV panels were purchased from Su-Kam Power Systems LTD. The PV panels are installed on the vehicle's roof to receive the maximum amount of solar radiation on sunny days and charge the battery bank in the daytime. These four panels are connected in series. The solar charge controller is 45 A capacity with an auto-recognition system. The vehicle's battery bank used four lead-acid batteries that are connected in series. The battery bank rated at $48 \mathrm{~V}$ with the capacity of $105 \mathrm{Ah}$ is used for energy storage and used as a power source for running the compressor and brushless direct-current (BLDC) motor. The battery protection circuit regulates the flow of charge and protects the battery bank from getting overcharged or getting deep discharged. The vehicle's refrigerator is driven by a DC compressor (K35 DC ROHS Sol-cool) operated in 12-12.6 V. A 48-12 V DC converter is used to supply the sufficient low voltage for the refrigerator. The low voltage disconnect (LVD) is used to control the energy fluctuations of the refrigerator. The LVD cuts off the energy supply from the refrigerator when the battery voltage reaches a critical level. A simple mode power supply battery charger (SMPS-15 A) was purchased from Fujiyama Power Systems PVT. LTD that used to charge the battery bank at night time.

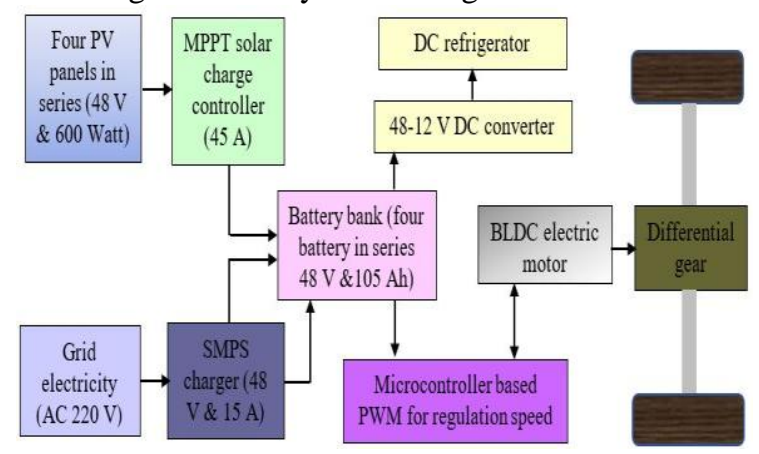

(a)

\section{Fig. 1.Example setup (a) block diagram (b) of SAREV.}

A solar pyranometer is used to measure the solar radiation falling on solar panels' surfaces. The complete set-up of SAREV is shown in figure 1 (a \& b).

\section{A. Experiment Conducted and Test Strategy}

To determine the main objectives of this study, a series of experiments were conducted on the vehicle's refrigerator with the hybrid energy mode (battery bank + solar energy). These experiments were completed at the Department of Mechanical Engineering, National Institute of Technology in Jalandhar city of Punjab state in India. These experiments were performed in the summer season (on 2-26 ${ }^{\text {th }}$ May 2020). All experiments are performed on the refrigerator in the vehicle's stationary condition. The refrigerator experiments are performed in the vehicle's stationary condition. Although the vehicle tests are performed on road condition. The refrigerator's walls temperatures are monitored with six PT100 thermocouples were purchased from Jiamin instrument CO. LTD. These thermocouples are positioned in the upper, middle, and lower parts of refrigerator compartments. The ambient air temperature is measured by one another thermocouple. The refrigerator voltages, currents, power, energy consumption, and all seven temperatures are recorded every 15 minutes time interval. Two digital watt-meters (DC PZEM-051) are used to measure the output energy of solar panels and the DC refrigerator's energy consumption. These watt-meters were purchased from Unitrend technology CO., LTD. The refrigerator experiments were divided into three steps. At the first step, the performance of PV panels was tested. The vehicle's refrigerator was tested by varying the thermostat position at the no-load condition in the second step. In the third step, the refrigerator's performance was tested in different load conditions ( $15 \mathrm{~L} \&$ then $25 \mathrm{~L}$ ). The water is used as a test material in the refrigerator loading experiments. The following experimental conditions were maintained across this study:

- The refrigerator chamber door was kept open for 8 hours to maintain thermal equilibrium with ambient air before starting each experiment. 


\section{Experimental Analysis of Hybrid Energy Operated Refrigerator Coupled In EV}

- The door of the refrigerator was kept closed during the experiment time.

- The battery bank of the vehicle must be fully charged before starting the experiment.

- The solar panels were always kept dust-free and no shade on them throughout the day.

- All these experiments were performed on the same location and same road route in sunny days conditions.

\section{RESULT AND DISCUSSION}

The temperature variation on the solar panel surface is shown in figure 2(a). The test period of the PV panel was selected from 8:00 a.m. to 6:00 p.m., due to the maximum solar radiation intensity available in this period.

The intensity of solar radiation finds a lower value (205 $\mathrm{W} / \mathrm{m}^{2}$ ) in the morning time, and it extends to its maximum value $\left(1050 \mathrm{~W} / \mathrm{m}^{2}\right)$ at noontime.

After that, it starts decreasing with the sunset until it goes to zero. The PV panel surface temperature

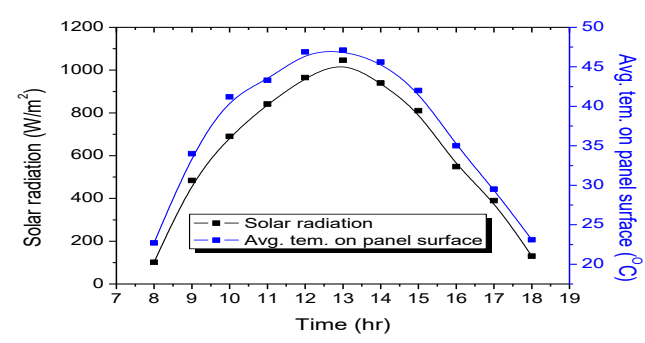

(a)

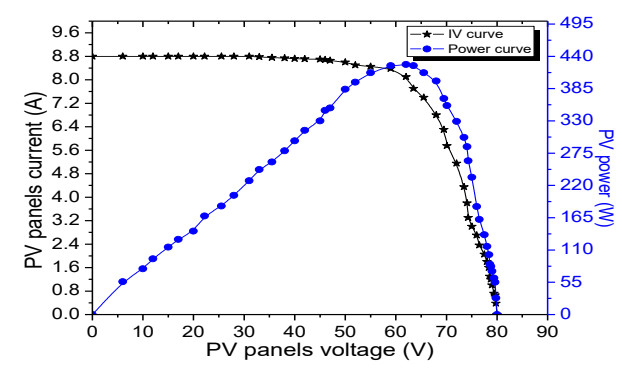

(b)

Fig. 2.The PV panel (a) surface temperature variation (b) IV and power curves.

increases with sunrise, and it reaches $45.3{ }^{\circ} \mathrm{C}$ temperature maximum at noontime and then decreases with sunset time. The temperature recorded on the solar panel surface is higher during the sun's peak hours than sunrise and sunset. The ambient air temperature increases with sunrise and reaches $44.2{ }^{\circ} \mathrm{C}$ maximum at noon, and decreases with sunset. The IV and power curves of the PV panel on a typical day are shown in figure 2(b). Due to the variation in solar irradiation on a typical sunny day, the PV current, voltage, and power output change in the range of $1.2-8.8 \mathrm{~A}, 10-62 \mathrm{~V}$, and $55-425 \mathrm{~W}$, respectively. The temperature variation rate is recorded slow on the solar panel surface compared to ambient air temperature variation. The solar energy generated yields about 2.5-4 units (kWh) of energy in a day time.

\section{A. The Refrigerator Performance Test}

The refrigerator performance experiments are tested at three different conditions: (1) without load, (2) with $15 \mathrm{~L}$ load, and (3) with $25 \mathrm{~L}$ load. These experiments are conducted with varying thermostat switch positions from 1-7 that affected the energy consumption of the refrigerator. The thermostat positions have been labelled on positions 1-7 to maintain the desired cut-off temperature from +6 to $-16{ }^{\circ} \mathrm{C}$ inside the refrigerator chamber. The refrigerator's circuit stops the power supply from running the compressor at a thermostat position zero. The performance of refrigerator parameters is studied through the different plots that are elaborated in the next section.

- The Performance of Refrigerator at No-load Condition: The refrigerator chamber is kept empty for conducting no-load experiments. figure 3(a) shows the average temperature variation profile for the different thermostat positions (1-7) inside the refrigerator chamber. The refrigerator compressor is permitted to run nonstop for one day on each thermostat position in the experimental period. The refrigerator compressor was allowed to run nonstop for one day on each thermostat position in the testing period. At thermostat position one, the refrigerator's inside temperature reaches $2.1{ }^{\circ} \mathrm{C}$ in $5.1 \mathrm{hrs}$. The refrigerator's compressor is switched off after reached $2.1{ }^{\circ} \mathrm{C}$ and automatically started running at $9{ }^{\circ} \mathrm{C}$. The cycling process occurs due to automatic the on/off of the compressor. For the thermostat positions 2, 3, 4, 5, 6, and 7, it takes $1 \mathrm{hr}, 1.5 \mathrm{hrs}, 2 \mathrm{hrs}, 2.1 \mathrm{hrs}, 4.3 \mathrm{hrs}$, and $6.5 \mathrm{hrs}$ respectively for the initial pull-down cycle. The lowest temperatures are recorded as $-1.9{ }^{\circ} \mathrm{C},-6.2{ }^{\circ} \mathrm{C},-7.3{ }^{\circ} \mathrm{C}$, $-10.6{ }^{\circ} \mathrm{C}$, $-12.4{ }^{\circ} \mathrm{C}$, and $-17.7{ }^{\circ} \mathrm{C}$ for the thermostat positions from 2 to 7 respectively. Refrigerator power consumption is illustrated in figure 4(b). Equations 1 \& 2 are used to calculate the power and energy consumption of the refrigerator.

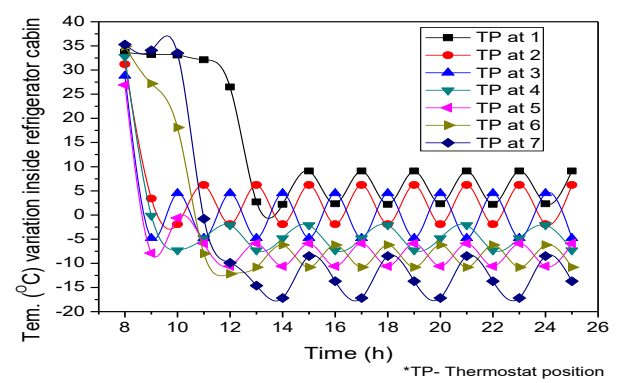

(a)

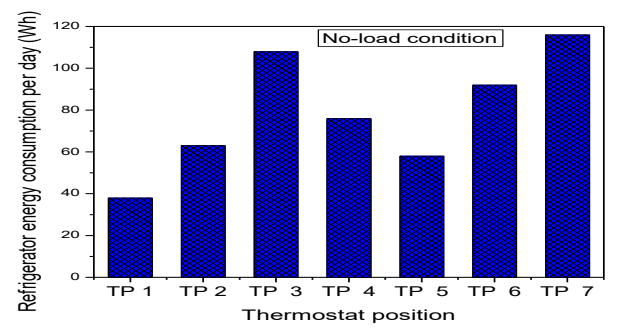

(b)

Fig. 3. The refrigerator (a) inside temperature variation (b) energy consumption.

Published By:

Blue Eyes Intelligence Engineering

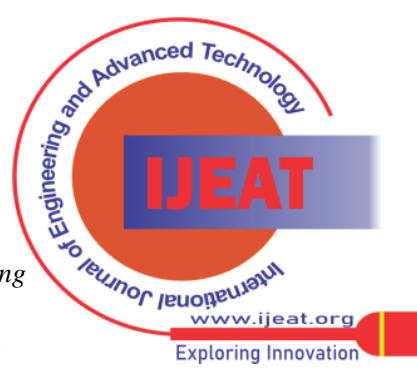


Power $=$ Current $\times$ Voltage

$P$ is the power consumption of the DC compressor, and $d t$ is the test run time. The refrigerator energy consumption is recorded as $38 \mathrm{Wh}, 63 \mathrm{Wh}, 108 \mathrm{Wh}, 76 \mathrm{Wh}$, $58 \mathrm{Wh}, 92 \mathrm{Wh}$, and $116 \mathrm{Wh}$ for the thermostat positions from 1 to 7 . The refrigerator's inside temperature was decreasing by increasing the thermostat position from 1 to 7 . The refrigerator was consuming higher energy at the $7^{\text {th }}$ thermostat position. At the $5^{\text {th }}$ thermostat position, the refrigerator maintains the lower desired temperature within the minimum time-period by consuming less energy.

- The Refrigerator Experiment with 15 L Load Condition: Figure 4(a) shows the average temperature variation inside the refrigerator chamber with the $15 \mathrm{~L}$ load at different thermostat positions. The refrigerator chamber was filled with 15 liters of water for conducting experiments. The refrigerator door closed after measuring the initial temperature of the water. The refrigerator's compressor was run continuously during experiments at different thermostat positions from one to seven. The inside temperature of the refrigerator was decreasing at a faster rate on the $3^{\text {rd }}$

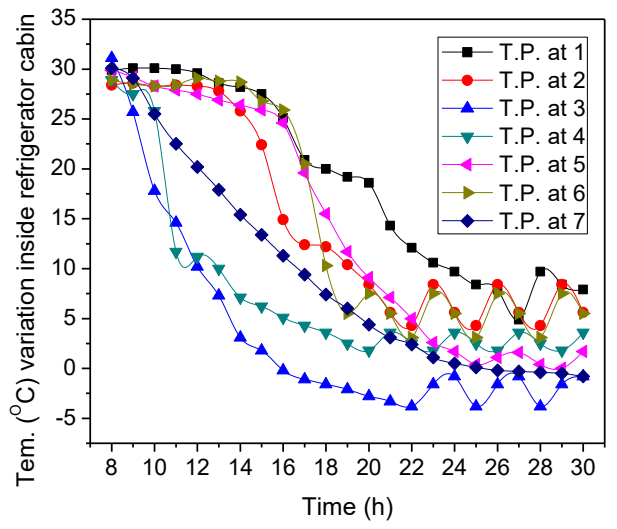

(a)

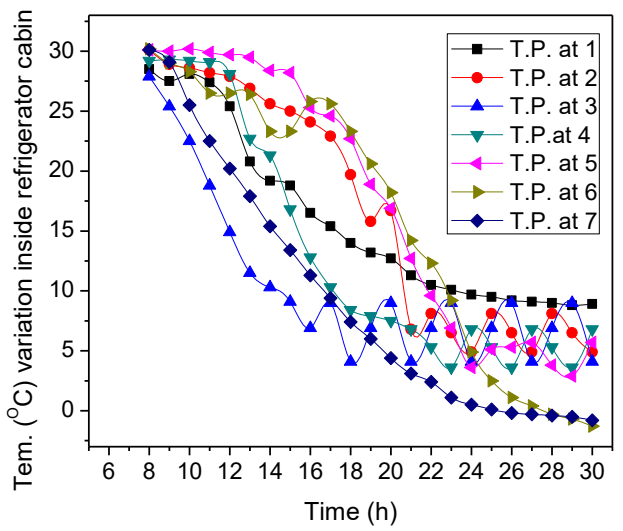

(b)

Fig. 4.The refrigerator experiment with (a) $15 \mathrm{~L}$ (b) $25 \mathrm{~L}$ load conditions.

$$
E_{\text {daily }}=\int_{0}^{24 h r} P . d t \sum_{t=0}^{24 h r} p \cdot \Delta t
$$

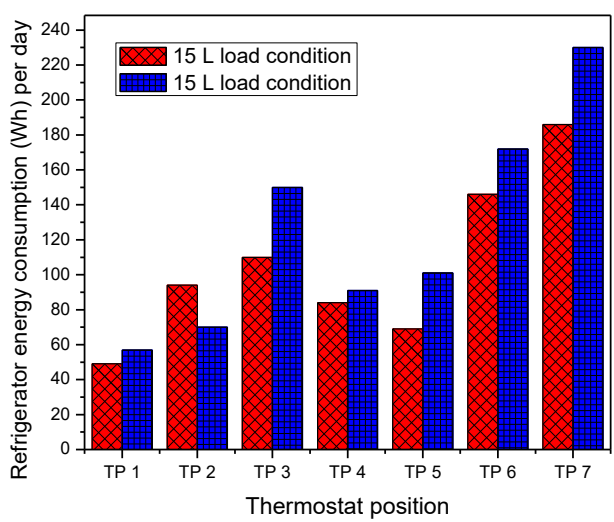

Fig.4(c). The refrigerator energy consumption for $15 \mathrm{~L}$ and $25 \mathrm{~L}$ load conditions.

thermostat position. The refrigerator's initial pull-down cycle time was smaller at the third thermostat position than the other thermostat positions.

- The Refrigerator Experiment with 25 L Load Condition: Figure 4(b) shows the average temperature variation inside the refrigerator cabin with the $25 \mathrm{~L}$ load at different thermostat positions. The refrigerator chamber was filled with 25 liters of water for conducting the experiments. The refrigerator's compressor was run continuously during experiment time at different thermostat positions from 1-7. The cabin's inside temperature decreased faster on the $3^{\text {rd }}$ thermostat position than the other thermostat positions. The $25 \mathrm{~L}$ load cycle started at a higher temperature than the $15 \mathrm{~L}$ load condition. However, the energy consumption was higher in $25 \mathrm{~L}$ load experiments. The cooling rate was recorded lower in the $25 \mathrm{~L}$ load condition than the $15 \mathrm{~L}$ load condition in the same time interval.

- The Refrigerator Energy Consumption for $15 \mathrm{~L}$ and $25 \mathrm{~L}$ Load conditions: Figure 4(c) shows the energy consumption of the refrigerator with load variation at different thermostat positions. The energy consumption of the refrigerator was depending on the compressor running time and thermostat position.

The refrigerator was consuming higher energy at thermostat position seven in all load conditions. The $15 \mathrm{~L}$ load condition's energy consumption was recorded as $49 \mathrm{Wh}, 94$ Wh, $110 \mathrm{Wh}, 84 \mathrm{Wh}, 69 \mathrm{Wh}, 146 \mathrm{Wh}$, and $186 \mathrm{Wh}$ for 1-7 thermostat positions. However, the $25 \mathrm{~L}$ load condition's energy consumption was recorded as $57 \mathrm{Wh}, 70 \mathrm{Wh}, 150$ Wh, $91 \mathrm{Wh}, 101 \mathrm{Wh}, 172 \mathrm{Wh}$, and $230 \mathrm{Wh}$ for 1 to 7 thermostat positions, respectively. The minimum energy consumption was recorded at the fourth and fifth thermostat positions.

- The Refrigerator Power Consumption at the $5^{\text {th }}$ Thermostat Position: The refrigerator power consumption with load variation at thermostat position five is shown in figure 5 . The power consumption was increasing with

Published By:

Blue Eyes Intelligence Engineering \& Sciences Publication

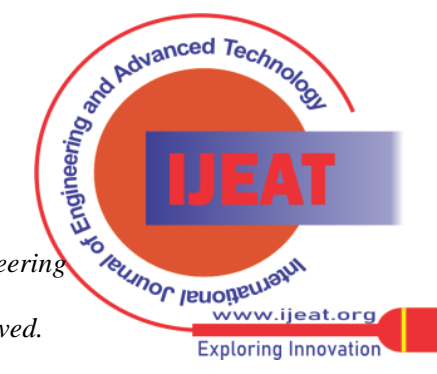




\section{Experimental Analysis of Hybrid Energy Operated Refrigerator Coupled In EV}

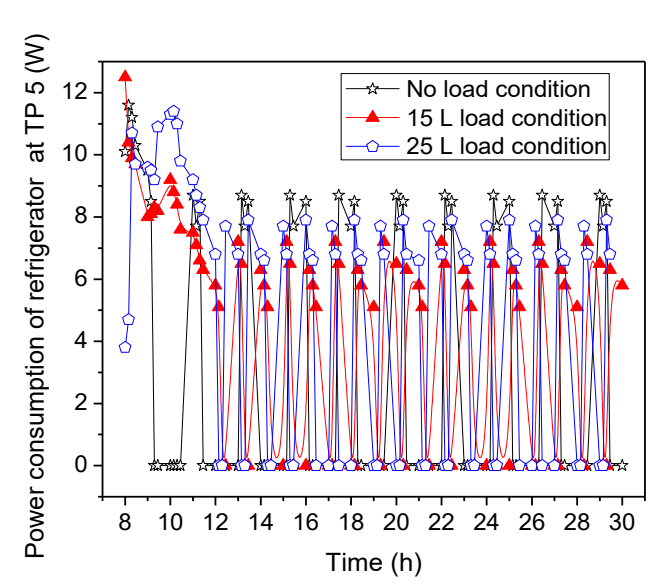

Fig. 5.The refrigerator power consumption at $5^{\text {th }}$ thermostat position.

increasing the load condition. The higher power consumption was $11.6 \mathrm{~W}$ recorded for each load condition at thermostat position 5. The initial power consumption was higher in each load condition; after that cycling process occurred (compressor on/off starts).

- The Refrigerator COP Variation in No-load condition: The refrigerator COP variation with compressor speed is shown in figure 6. The refrigerator COP was decreasing with the increasing compressor speed. The COP was recorded higher (1.32) at the lower speed (2000 rpm) and lower (1.17) at the higher speed of the compressor (3600 rpm).

- Vehicle Distance travelled with load variation: The distance covered by the vehicle with load variation in different energy modes is shown in Figure 7. The vehicle was covering a higher distance in hybrid energy mode for each load condition. The travelling distance was decreasing with increasing load on the vehicle. However, vehicle energy consumption was increasing with the increasing load on the vehicle. The vehicle was travelling $68.3 \mathrm{~km}, 65.3 .6 \mathrm{~km}, 63.4$ $\mathrm{km}$ distance in no-load, $100 \mathrm{~kg}$, and $200 \mathrm{~kg}$ load conditions respectively by consuming $3010 \mathrm{Wh}, 3230 \mathrm{Wh}$, and 3450 Wh energy.

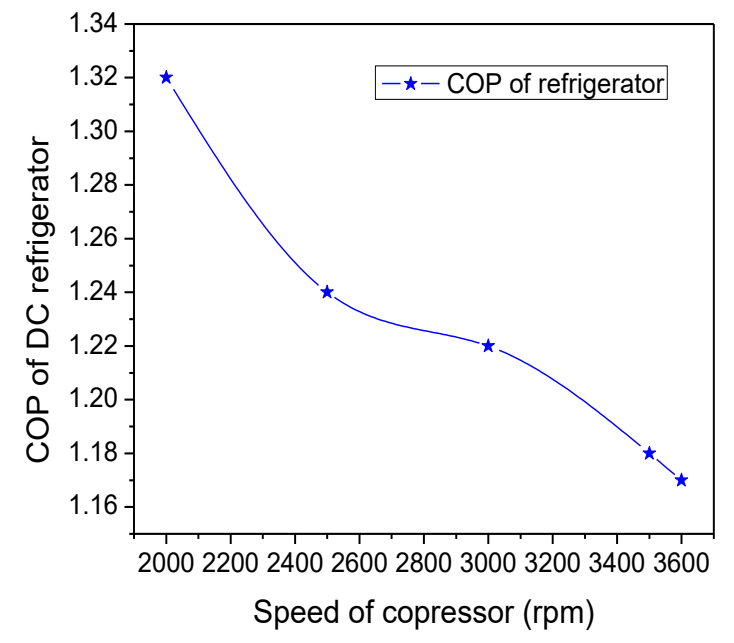

Fig. 6.The COP of refrigerator variation with compressor speed.

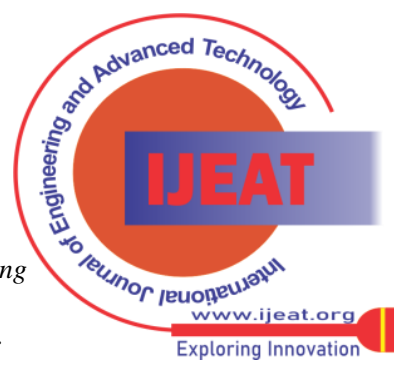

The solar-assisted refrigerator of the electric vehicle has conditions. The integral system of this vehicle is an economical and energy-efficient technique for intercity cold chain transportation. The essential outcomes of this research

energy on the average sunny day.

- The maximum output current and power of PV panels were recorded as $8.8 \mathrm{~A}$ and $425 \mathrm{~W}$, respectively.

The refrigerator's energy consumption at no-load was

Wh for 1-7 thermostat positions.

- For 25 L load, the energy consumption was varying 57-230

Wh for 1-7 thermostat positions. $2.5^{\circ} \mathrm{C}$ for the no-load, $15 \mathrm{~L}$ load, and $25 \mathrm{~L}$ load conditions, respectively.

increasing compressor speed.

- The COP was recorded higher (1.32) at the lower speed (2000 rpm) and lower (1.17) at the higher speed of the compressor (3600 rpm).

The refrigerator's inside temperature was decreasing faster the third thermostat position among all load conditions.

The refrigerator was consuming higher energy at the 7

- At the higher thermostat position, the battery bank was able to run the refrigerator $240 \mathrm{hr}, 96 \mathrm{hr}, 72 \mathrm{hr}$ for the no-load, $15 \mathrm{~L}$ load, and $25 \mathrm{~L}$ load conditions. 
- The vehicle was travelling $68.3 \mathrm{~km}, 65.3 .6 \mathrm{~km}, 63.4 \mathrm{~km}$ distance in no-load, $100 \mathrm{~kg}$, and $200 \mathrm{~kg}$ load conditions respectively by consuming $3010 \mathrm{Wh}, 3230 \mathrm{Wh}$, and 3450 Wh energy.

- The travelling cost of the vehicle was 1-1.5 INR per kilometer.

\section{ACKNOWLEDGMENT}

This project was supported by the National Institute of Technology Jalandhar of India in TEQIP-II (R \& D/1625).

\section{REFERENCES}

1. O. Adekomaya, T. Jamiru, R. Sadiku, and Z. Huan, "Sustaining the shelf life of fresh food in the cold chain-A burden on the environment," Alexandria Engineering Journal, vol. 55, no. 2, pp. 1359-1365, 2016.

2. Y. Wang, L. Qiu, J. Liu, X. Xu, J. Bao, and J. Zhu, "Performance of a fresh-food storage box based on semiconductor refrigeration," Sustainable Cities and Society, vol. 49, pp. 1-9, 2019.

3. R. B. Melis, U. M. Carthy, L. R. Garcia, J. G. Hierro, J. R. Villalba, "New trends in cold chain monitoring applications-A review," Food Control, vol. 86, pp. 170-182, 2018.

4. S. Melo, P. Baptista, and A. Costa, "Comparing the use of small-sized electric vehicles with diesel vans on city logistics," Procedia-Social and Behavioral Sciences, vol. 11, no. 1, pp. 1265-1274, 2014.

5. Shamayleh A, Hariga M, Asad R, Diabat A, "Economic and environmental models for cold products with time-varying demand," Journal of cleaner production, vol. 212, pp. 847-863, 2019.

6. R. Accorsi, A. Gallo, and R. Manzini, "A climate-driven decision-support model for the distribution of perishable products," Journal of cleaner production, vol. 165, pp. 917-929, 2017.

7. A. Saif and S. Elhedhli, "Cold supply chain design with environmental considerations: a simulation-optimization approach,” European Journal of Operational Research, vol. 251, no. 1, pp. 274-287, 2016.

8. S. Arshdeep, S. L. Shimi, Nikhi, "Design and analysis of off-board PV-grid adjustable Charger for the electric vehicle battery," International Journal of Recent Technology and Engineering vol. 9, no. 3, pp. 1005-1013, 2020.

9. M. N. Pavan, V. K. Vijayendra, M. S. Shashikala, "Self-sustainable off-grid electric vehicle (EV) charging station with the integration of renewable sources," International Journal of Recent Technology and Engineering, vol. 9, no. 3, pp. 2669-2674, 2020.

10. G. Schliwa, R. Armitage, S. Aziz, J. Evans, and J. Rhoades, "Sustainable city logistics-making cargo cycles viable for urban freight transport," Research in Transportation Business \& Management, vol. 15, pp. 50-57, 2015.

11. A. Meneghetti and S. Ceschia, "Energy-efficient frozen food transports: the refrigerated routing problem," International Journal of Production Research, vol. 58, no. 4164-4181, pp. 1-8, 2020.

12. Y. Zhao, N. C. Onat, M. Kucukvar, and O. Tatari, "Carbon and energy footprints of electric delivery trucks: a hybrid multi-regional input-output life cycle assessment," Transportation Research Part D: Transport and Environment, vol. 47, pp. 195-207, 2016.

13. J. Kast, G. Morrison, J. J. Gangloff Jr, R. Vijayagopal, and J. Marcinkoski, "Designing hydrogen fuel cell electric trucks in a diverse medium and heavy-duty market," Research in Transportation Economics, vol. 70, pp. 139-147, 2018.

14. H. Liimatainen, O. V. Vliet, and D. Aplyn, "The potential of electric trucks-an international commodity-level analysis," Applied Energy, vol. 236, pp. 804-814, 2019.

15. R. Yadav and R. P. Singh, "Rural electrification: Practical exposition of hybrid solar PV-wind for grid integrated power systems in India," International Journal of Engineering and Advanced Technology, vol. 9, no. 3, pp. 680-687, 2020.

16. A. Modi, A. Chaudhuri, B. Vijay, and J. Mathur, "Performance analysis of a solar photovoltaic operated domestic refrigerator," Applied Energy, vol. 86, no. 12, pp. 2583-2591, 2009.

17. O. Ekren, S. Celik, B. Noble, and R. Krauss, "Performance evaluation of a variable speed DC compressor," International Journal of Refrigeration, vol. 36, no. 3, pp. 745-757, 2013.

18. R. Opoku, S. Anane, I. A. Edwin, M. S. Adaramola, and R. Seidu, "Comparative techno-economic assessment of a converted DC refrigerator and a conventional AC refrigerator both powered by solar PV," International Journal of Refrigeration, vol. 72, pp. 1-11, 2016.
19. V. T. Toledo, K. Meissner, P. Taschner, S. M. Ballester, and J. Muller, "Design and performance of a small-scale solar ice-maker based on a DC-freezer and an adaptive control unit," Solar Energy, vol. 139, pp. 433-443, 2016.

20. N. I. Ibrahim, M. M. A. Khan, I. M. Mahbubul, R. Saidur, F. A. A. Sulaiman, "Experimental testing of the performance of a solar absorption cooling system assisted with ice-storage for an office space,' Energy Conversion and Management, vol. 148, pp. 1399-1408, 2017.

21. K. O. Daffallah, M. Benghanem, S. N. Alamri, A. A. Joraid, and A. A. Al-Mashraqi, "Experimental evaluation of photovoltaic DC refrigerator under different thermostat settings," Renewable Energy, vol. 113, pp. 1150-1159, 2017.

22. Y. Xu, M. Li, X. Luo, X. Ma, Y. Wang, G. Li, and R. H. Hassanien, "Experimental investigation of solar photovoltaic operated ice thermal storage air-conditioning system," International Journal of Refrigeration, vol. 86, pp. 258-272, 2018.

23. S. Sidney, R. Prabakaran, and M. L. Dhasan, "Charge optimization of a solar milk chiller with direct current compressors," Journal of Process Mechanical Engineering, vol. 6, no. 5, pp. 1-14, 2021.

24. K. O. Daffallah, "Experimental study of $12 \mathrm{~V}$ and $24 \mathrm{~V}$ photovoltaic DC refrigerator at different operating conditions," Physics B: Condensed Matter. vol. 545, pp. 237-244, 2018.

25. E. M. Salilih and Y. T. Birhane, "Modeling and performance analysis of directly coupled vapor compression solar refrigeration system," Solar Energy, vol. 190, pp. 228-238, 2019.

26. S. Kumar, and R. S. Bharj, "Experimental analysis of a light-weight refrigerated electric vehicle in the summer and winter season," In AIP Conference Proceedings, vol. 545, no. 1, pp. 1-8, 2021.

27. B. Dhananjaya and Satyendra Kumar, "Determination of characteristics of DC motors used in light motor electric vehicles using inter operable cad \& femm," International Journal of Recent Technology and Engineering, vol. 9, no. 3, pp. 85-92, 2020.

28. J. Kast, R. Vijayagopal, J. J. Gangloff Jr, and J. Marcinkoski, “Clean commercial transportation: Medium and heavy-duty fuel cell electric trucks," International Journal of Hydrogen Energy, vol. 42, no. 7, pp. 4508-4517, 2017.

29. D. F. Dominkoviv, I. Bacekovic, A. S. Pedersen, and G. Krajacic, "The future of transportation in sustainable energy systems: Opportunities and barriers in a clean energy transition," Renewable and Sustainable Energy Reviews, vol. 82, pp. 1823-1838, 2018.

30. V. B. Raju and C. Chengaiah, "A novel T-C-T solar photovoltaic array configurations using rearrangement of PV modules with shade dispersion technique for enhancing the array power," International Journal of Recent Technology and Engineering, vol. 8, pp. 68-78, 2020

\section{AUTHORS PROFILE}

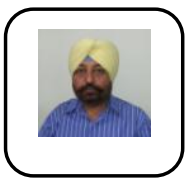

Dr. R. S. Bharj, currently working as Associate Professor, Dr B. R. Ambedkar National Institute of Technology Jalandhar (Punjab), India. He carries academic and administrative experience of more than 25 years. He has supervised 6 Ph.D. and more than 25 M.Tech. students working in the field of Mechanical Engineering. He has authored more than 60 published technical papers, and co-authored book chapters. His areas of interest are Renewable and Appropriate Energy Systems, Alternate Fuels, IC Engines and Automobile Engineering and Electric Vehicles.

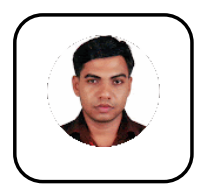

Surender Kumar is currently pursuing Ph.D. in the Department of Mechanical Engineering, Dr B. R. Ambedkar National Institute of Technology Jalandhar, Jalandhar (Punjab), India. 